\title{
Status and impacts of invasive alien plant species in Parsa National Park, central Nepal
}

\author{
R. Chaudhary ${ }^{1}$, B. B. Shrestha ${ }^{1 *}$, H. Thapa ${ }^{1}$ and M. Siwakoti ${ }^{1}$
}

\begin{abstract}
Extent of plant invasions has been expected to be low in protected areas such as national parks due to low anthropogenic activities and high wilderness. However, recent researches across the world have revealed that plant invasions can be severe in the national parks with negative impacts on the protected species and ecosystems. Unfortunately, the status of plant invasions in the national parks of Nepal is mostly unknown. In this study, we sampled at seven locations inside the Parsa National Park (PNP) to document diversity and abundance of invasive alien plant species (IAPS) and their impacts on tree regeneration. Altogether, 130 quadrats of $10 \mathrm{~m} \times 10 \mathrm{~m}$ were sampled. We recorded 14 IAPS in the PNP. Three of the IAPS (Chromolana odorata, Lantana camara and Mikania micrantha) were among the 100 of the world's worst invasive alien species. C. odorata was found to be the most frequent IAPS with the highest cover. The frequency and cover of the IAPS were higher at the sites close to the settlements than at the sites away from the settlements. The species richness of the IAPS was also higher at the sites closer to the settlements than away. The sapling density of the tree species was found to have declined with the increasing cover of the IAPS suggesting that the IAPS had negatively affected tree regeneration. Our data revealed that the PNP has already witnessed massive plant invasions with widespread occurrence of three of the world's worst invasive species. Therefore, it is high time to integrate management of invasive alien species in the management plan of the park.
\end{abstract}

Keywords: Biological invasions, Chromolaena odorata, protected areas, species richness, tree regeneration

A ny plant species that are native to one region but have been introduced into an area outside their natural distribution range where they colonize and threaten biological diversity, ecosystems and human well-beings are considered as the invasive alien plant species (IAPS), and the processes are known as biological invasions (CBD, 2002). The IAPS can display strong allelopathic properties (Rai and Tripathi, 1982), rapid vegetative growth, prolific seed production capacity (Norbu, 2004), long-lived seeds, early maturation to sexually reproductive stage, phenotypic plasticity and ability to survive in a wide range of environmental conditions (Tiwari et al., 2005). The IAPS can display several negative impacts in wide range of field such as biodiversity, ecosystems, human health and livelihood, agriculture and aquaculture, and can cause economic losses (Rai and Singh, 2020). Invasion by IAPS is often associated with out-competing native species and homogenizing ecosystems, changing hydrological characteristics, degrading gene pools through hybridization with native species resulting biodiversity loss (Miththapala, 2007; Richburg, 2008; Hui et al., 2011). These damages are aggravated by climate change (Kriticos et al., 2003), pollution, habitat loss and human-induced disturbances (Norbu, 2004; Kohli et al., 2009). The IAPS can break the plantconsumer interactions, drive population declines and species extinction (Donlan et al., 2003; Reaser et al., 2007; Dangermond et al., 2010).

1. Central Department of Botany, Tribhuvan University, Kirtipur, Kathmandu, Nepal, *E-mail: shresthabb@gmail.com 
The problem of plant invasions is also escalating in Nepal (Shrestha, 2019). Altogether, 179 species of naturalized plants have been reported from Nepal (Shrestha et al., 2017), and 26 of them are considered invasive (Shrestha, 2019). Some IAPS, such as Ageratina adenophora (Chettri, 1986), Chromolaena odorata (Norbu, 2004), Mikania micrantha (Sapkota, 2012; Rai and Scarborough, 2012), Lantana camara and Hyptis suaveolens are serious IAPS disrupting forests and shrub lands in Nepal (Tiwari et al., 2005). Similarly, Parthenium hysterophorus has been expanding its distribution from urban areas and grasslands to forest ecosystems including the habitats of endangered mammals (Shrestha et al., 2015, 2019).

The introduction and colonization of IAPS is one of the serious threats to different protected areas, particularly the lowlands of Nepal. The IAPS like C. odorata, M. micrantha, L. camara, Ipomoea carnea and $P$. hysterophorus were the most common and problematic species in the national parks and wildlife reserves of the Terai region in Nepal (Bhuju et al., 2013). M. micrantha has proliferated rapidly in forest, grasslands and wetland areas, and has been categorized as the most serious weed of Chitwan National Park (Sapkota, 2012, Murphy et al. 2013). The invasion of such IAPS disrupts the ecosystems in the Park, and may disturb the lives of flagship species and various threatened floras and faunas (e.g. Murphey et al., 2013). The management of such IAPS requires park specific data related to the IAPS diversity, their abundance and impacts on native species. In this context, the present study was undertaken with the following objectives: i) to identify the IAPS invading the Parsa National Park, and analyze their abundance; ii) to analyze how the species richness of the IAPS vary spatially within the Park, and iii) to assess the impacts of the IAPS on the regeneration of tree species. The data generated from this study is useful for the management of the IAPS in the Parsa National Park (PNP).

\section{Materials and methods Study area}

The study was conducted in the Parsa National Park (PNP) which is located in the southcentral lowland Terai of Nepal (Figure 1).
The Park extends over $627.39 \mathrm{~km}^{2}$ area, and is located between $27^{\circ} 13^{\prime} 52^{\prime \prime} \mathrm{N}$ and $27^{\circ} 32^{\prime} 26^{\prime \prime}$ $\mathrm{N}$ latitudes, and 84 $40^{\prime} 22^{\prime \prime} \mathrm{E}$ and $84^{\circ} 58^{\prime} 41^{\prime \prime} \mathrm{E}$ longitudes (DNPWC/PCP, 2003). It partially covers three districts, viz. Parsa, Makawanpur and Bara. Most of the Park's landscape consists of Siwalik Hills. The soil is primarily composed of gravel and conglomerates susceptible to erosion. The foothills are very porous; hence, water is scarce in this Park (Bhuju et al., 2007). The Park has eight types of ecosystems and two types of forest vegetation with 298 species of vascular plants, 37 mammals, 503 birds, 8 herpeto and 8 fish species (Bhuju et al., 2007). The forest in the Park is mostly composed of Sal (Shorea robusta) mixed with broadleaved vegetation. The Park focuses on the protection of plants like Dalbergia latifolia (Satisal) and faunas like Bos frontalis gaurus (Gaur), Elephas maximus (Elephant), Panthera tigris (Tiger), Rhinoceros unicornis (Rhino) and Python molurus (Python). The main threats to the biodiversity of the Park are the illegal hunting and poaching, illegal collection of non-timber forest products (NTFPs) and rapid spread of IAPS (DNPWC, 2003).

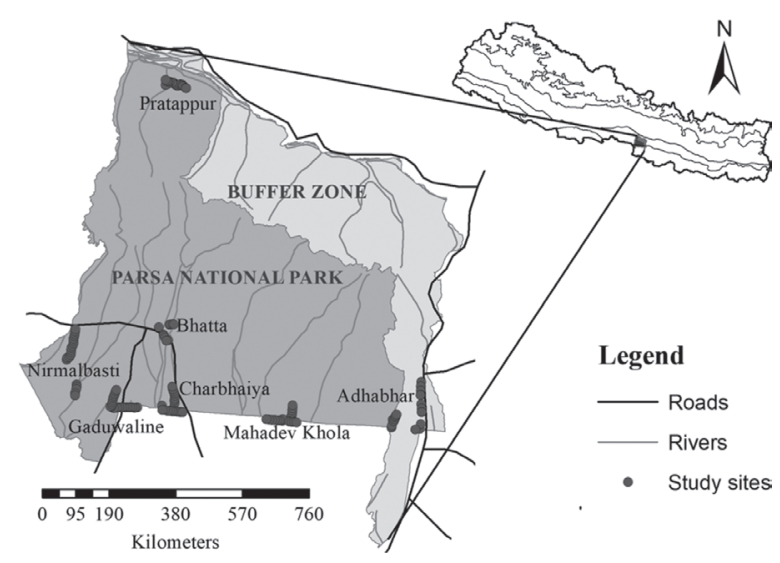

Figure 1: Map showing the sampling sites and locations of sample plots within the PNP (The map was prepared using the ArcGIS version 10)

According to the records of the Hetauda Weather Station, which is located at about $12 \mathrm{~km}$ north-east from the study area, the average annual rainfall of the study area is $2,256 \mathrm{~mm}$ with more than 90\% rainfall during May-September, and highest during July and August (Figure 2). The monthly mean temperature ranges from a minimum of $17^{\circ} \mathrm{C}$ to a maximum of $30^{\circ} \mathrm{C}$. 


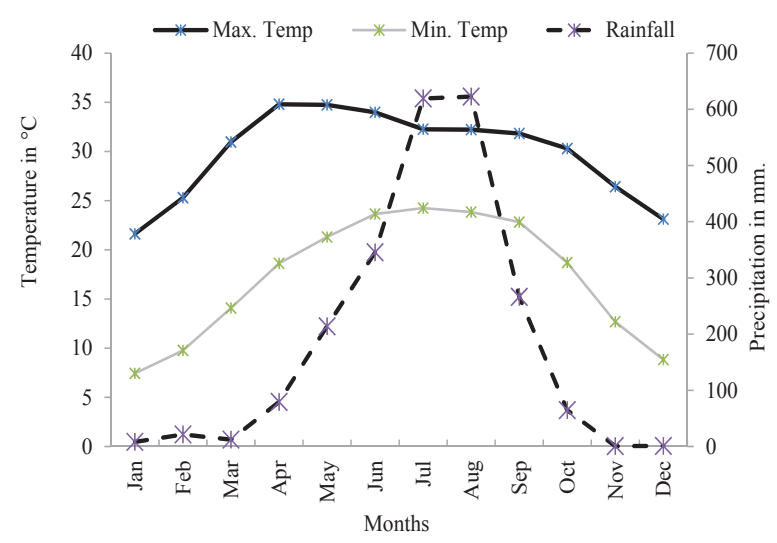

Figure 2: Five-year (2009-2013) average minimum and maximum temperatures and monthly precipitation recorded at Hetauda Weather Station. (Source: Department of Hydrology and Meteorology, Government of Nepal)

\section{Vegetation sampling}

The field data were collected through vegetation sampling using quadrat method. Considering representativeness and accessibility of the potential sampling sites and safety from wildlife, we selected Adhabhar, Mahadev Khola, Charbhaiya, Gadualine, Nirmalbasti, Bhata and Pratappur areas for sampling (see Figure 1 above). These were also the sites where security posts of the Park were located. Among them, three sites (Adhabhar, Bhata and Pratappur) were close to the human settlement, and the remaining four were away from the settlements. At each of the six sites except Bhata, 20 quadrats $(10 \mathrm{~m} \times 10 \mathrm{~m})$ were sampled within a distance of about $200-250 \mathrm{~m}$. At the Bhata Site, only 10 quadrats were sampled due to the high risk of wild animal. Therefore, the total number of quadrats sampled was 130 . In each quadrat, we recorded the flowering plant species, and visually estimated the cover of both the individual IAPS as well as the combination of all the IAPS. Besides, we measured the diameters of the tree trunks at breast height $(137 \mathrm{~cm}, \mathrm{DBH})$ and counted the number of saplings (height $>137 \mathrm{~cm}$ and $\mathrm{DBH}<10 \mathrm{~cm}$ ) of all the tree species and fire marks (i.e. presence/ absence of burnt plant parts). In addition, the geographic locations (latitude, longitude and elevation) of all the quadrats were recorded with the help of Global Positioning System (GPS) Receiver. The herbarium specimens of all the flowering plants were collected.

\section{Plant identification}

Flowering plant species were identified on the basis of their morphological features with the help of a number of references (e.g. Polunin and Stainton, 1984; Grierson and Long, 1984, 1987, 1991, 1999 and 2001; Malla et al.,1986; Siwakoti and Varma, 1999; Press et al., 2000; Wu et al., 2011; Bhuju et al., 2013). We identified the invasive alien plant species (IAPS) following Tiwari et al. (2005).

\section{Data analysis}

The flowering plant species were categorized into dicotyledonous and monocotyledonous. They were further categorized into different life forms such as tree, shrub, climber and herb. The frequencies of the IAPS for each site were calculated separately in terms of the percentage of the quadrat. Similarly, the cover values of the individual IAPS for each site was calculated in terms of the mean of the cover values estimated for each quadrat. These site-wise frequencies and cover values of the IAPS are presented in Table 1. The frequencies and cover values of the IAPS for the PNP were calculated using the methods mentioned above by pooling the data of the three sites (Adhabhar, Bhata and Pratappur) which are close to the human settlements and another four sites (Mahadev Khola, Charbhaiya, Gadualine, and Nirmalbasti) which are far from the settlements. That means the combined frequencies and covers of the IAPS were calculated for two groups of the sites, viz. i) near the settlements and ii) away from the settlements. The combined cover value $(0-100 \%)$ of all the IAPS present in each quadrat was converted to Domin Cover Scales to minimize the errors and to normalize the data (Kent and Coker, 1994). The Domin Cover Scales were 1=1-2 individuals with no measurable cover, $2=$ several individuals but less than $1 \%$ cover, $3=1-4 \%$ cover, $4=4.1-10 \%$ cover, $5=10.1-25 \%$ cover, $6=25.1-33 \%$ cover, $7=33.1-50 \% \quad$ cover, $8=50.1-75 \% \quad$ cover, $9=75.1-90 \%$ cover, $10=90.1-100 \%$ cover. These cover classes were used to compare the IAPS cover by independent sample t-test between the sites close to and away from the settlements; between quadrats with and without fire marks. Using the same method, the species richness of the IAPS (i.e. the no. of IAPS/quadrat) was also compared between sites. Analysis of variance (ANOVA) was used to compare the cover class values and the IAPS species richness among seven sites. 
In order to access the impact of the IAPS on tree regeneration, the variation of tree sapling density with the combined cover percentage of all the IAPS was analyzed with the help of linear regression. Before accomplishing the statistical analyses, the data were checked for normality (Kolmogorov-Smirnov Test) and homogeneity of variance (Levene's Test). All the statistical analyses were accomplished using the Statistical Package for Social Sciences (SPSS, version 16.0).

\section{Results}

\section{Flowering plant species}

Altogether, we recorded 231 flowering plant species belonging to 63 families from the sampling sites of the PNP (Figure 3). Majority of them were found to be dicotyledonous. In terms of life forms, the highest number of species belonged to herb. Among all the flowering plants, 14 species were IAPS.

\section{$\square$ Dicotyledonous $\square$ Monocotyledonous}

A)

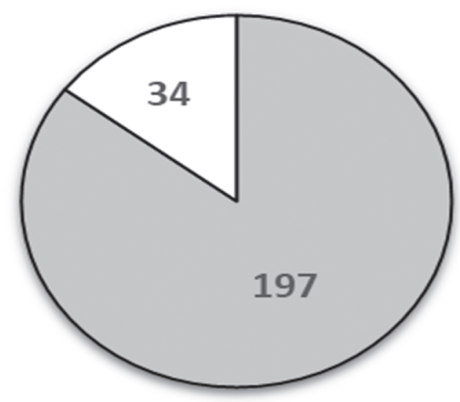

B)

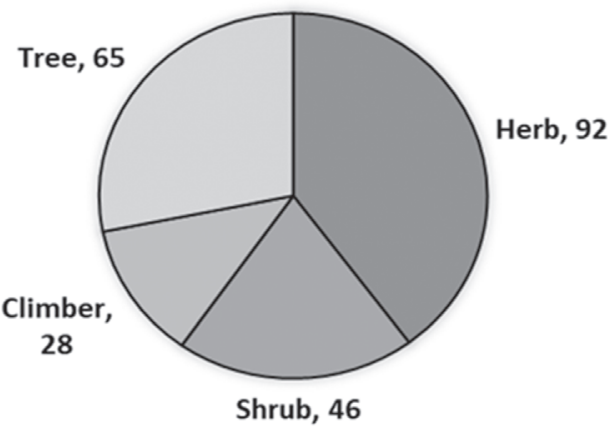

Figure 3 (A - B): Diversity of the flowering plants collected within the sampling sites.

\section{Frequency, cover and richness of the IAPS}

We recorded 14 IAPS representing 5 families in the PNP (Figure 4 and Table 1). The most species riches family was found to be Asteraceae with 7 species followed by Fabaceae with 3 species, Amaranthaceae with 2 species, Lamiaceae and
Verbenaceae, each with 1 species. Among them, C. odorata had the highest frequency and cover (Figure $4 \mathrm{a}$ and Figure $4 \mathrm{~b}$ ). The frequency and cover of each IAPS within the sites near the settlements were found to be always higher as compared to the ones within the sites away from the settlements (Figure 4). Across the sampling sites, C. odorata was the most frequent IAPS with the highest cover in all the sampling sites except in the Bhata Site where Senna tora was the most frequent but $M$. micrantha had the highest cover (Table 1).

When the coverages of all the IAPS was combined, it was found to be higher near the settlements than away from the settlements (Table 2a) and lower in the plots with fire marks than the ones without fire mark (Table 2b). Similarly, the cover of all the IAPS combined was higher at Bhata and Pratappur Sites than at the other sampling sites (Table 2c).
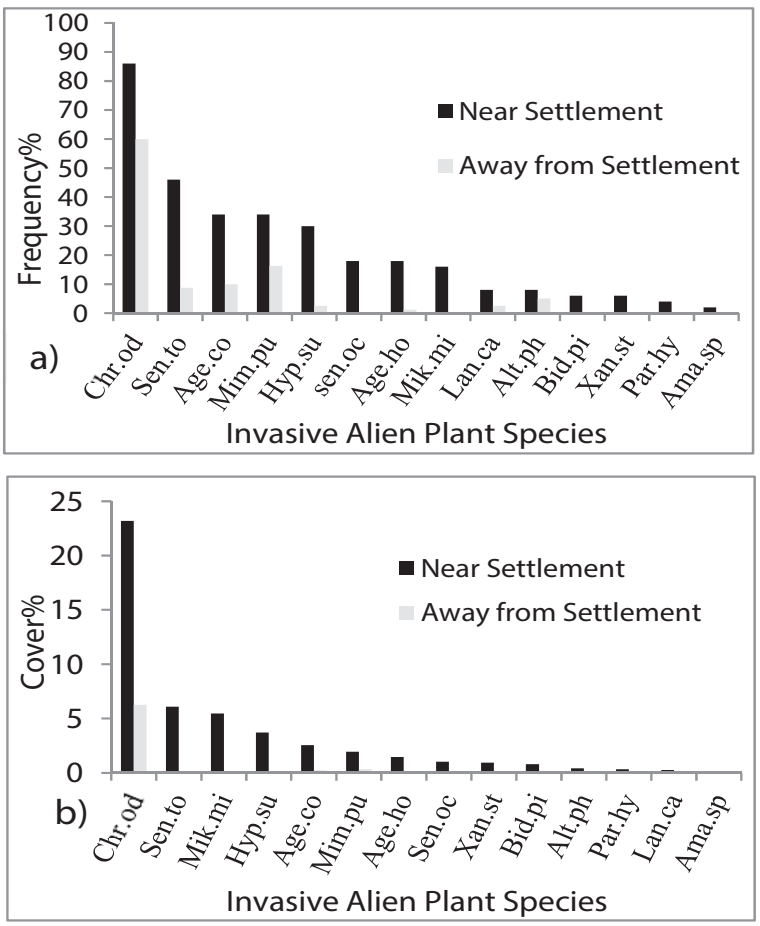

Figure 4 (a): Frequency of the IAPS near and away from the settlements, and Figure 4 (b): Cover of the IAPS near and away from the settlements. (Note: Chrod=Chromolaena odorata, Sen.to=Senna tora, Mim.pu=Mimosa pudica, Age.co=Ageratum conyzoides, Hyp.su =Hyptis suaveolens, Sen.oc=Senna occidentalis, Age. ho=Ageratum houstonianum, Mik.mi=Mikania micrantha, Alt.ph=Alternanthera philoxeroides, Lan.ca $=$ Lantana camara, Bid.pi=Bidens pilosa, Xan.st=Xanthium strumarium, Par.hy=Parthenium hysterophorus and Ama.sp=Amaranthus spinosus). 


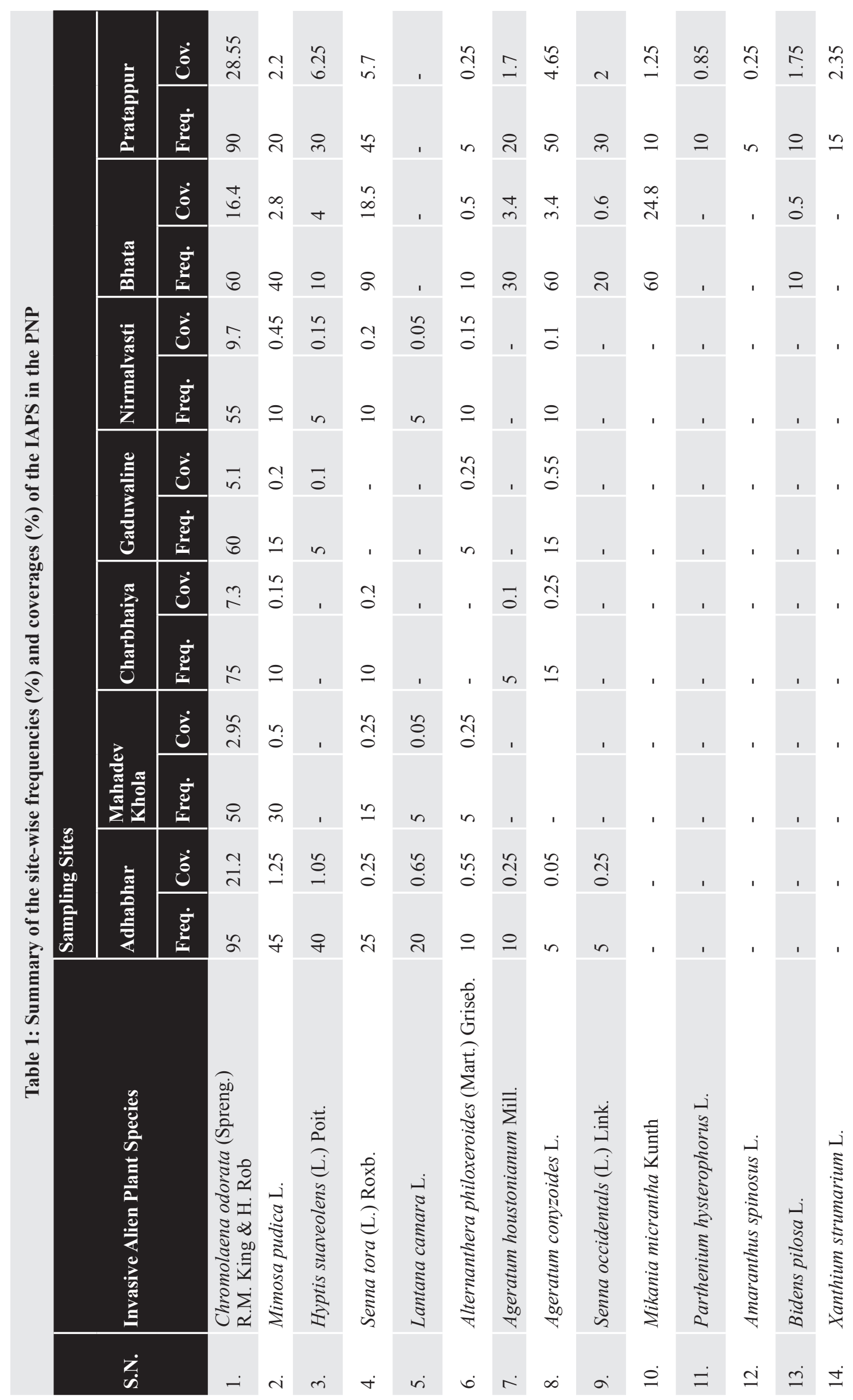


Table 2: Mean coverages and species richness of the IAPS

\section{a) Near and away from the settlements}

\begin{tabular}{|c|c|c|c|}
\hline \multicolumn{2}{|l|}{ Samples \& tests } & $\begin{array}{l}\text { Domin Cov. Scale of } \\
\text { IAPS }(\bar{\chi} \pm \text { S.E. })\end{array}$ & IAPS Richness $(\bar{\chi} \pm$ S.E. $)$ \\
\hline \multirow[t]{2}{*}{ Settlement Status } & Near settlements & $6.32 \pm 0.29$ & $3.3 \pm 0.16$ \\
\hline & Away from settlements & $2.72 \pm 0.22$ & $1.29 \pm 0.11$ \\
\hline \multirow{3}{*}{$\begin{array}{l}\text { Levene's Test for } \\
\text { equality of variances } \\
\text { t-test }\end{array}$} & F-value & 0.406 & 0.491 \\
\hline & Sig.-value & 0.525 & 0.485 \\
\hline & Sig.-value & 0.000 & 0.000 \\
\hline
\end{tabular}

b) With and without fire marks

\begin{tabular}{|c|c|c|c|}
\hline \multirow[t]{2}{*}{ Fire mark status } & No fire mark & $4.7 \pm 0.31$ & $2.35 \pm 0.16$ \\
\hline & Fire mark & $3.2 \pm 0.33$ & $1.61 \pm 0.18$ \\
\hline \multirow{3}{*}{$\begin{array}{l}\text { Levene's Test of } \\
\text { equality of variances }\end{array}$} & F-value & 2.041 & 2.260 \\
\hline & Sig.-value & 0.156 & 0.135 \\
\hline & Sig.-value & 0.001 & 0.002 \\
\hline
\end{tabular}

c) Different sampling sites

\begin{tabular}{|c|c|c|c|}
\hline \multirow{7}{*}{ Sampling Sites } & Adhabhar & $4.95 \pm 0.45$ & $2.80 \pm 0.27$ \\
\hline & Mahadev Kohola & $2.00 \pm 0.36$ & $1.10 \pm 0.19$ \\
\hline & Charbhaiya & $2.85 \pm 0.47$ & $1.25 \pm 0.24$ \\
\hline & Gaduwaline & $2.70 \pm 0.44$ & $1.25 \pm 0.22$ \\
\hline & Nirmalvasti & $3.35 \pm 0.49$ & $1.55 \pm 0.23$ \\
\hline & Bhata & $8.00 \pm 0.42$ & $3.80 \pm 0.25$ \\
\hline & Pratappur & $6.85 \pm 0.38$ & $3.55 \pm 0.22$ \\
\hline $\begin{array}{l}\text { Leven's Test of } \\
\text { equality of variances }\end{array}$ & Sig.-value & 0.465 & 0.691 \\
\hline \multirow{2}{*}{ ANOVA } & F-value & 22.578 & 22.047 \\
\hline & Sig.-value & $<0.001$ & $<0.001$ \\
\hline
\end{tabular}

(Note: Domin Cover Scale of IAPS: $1=1-2$ individuals with no measurable cover, $2=$ several individuals but $<1 \%$ cover, $3=1-4 \%$ cover, $4=4.1-10 \%$ cover, $5=10.1-25 \%$ cover, $6=25.1-33 \%$ cover, $7=33.1-50 \%$ cover, $8=50.1-75 \%$ cover, $9=75.1-90 \%$ cover and $10=90.1-100 \%$ cover of the IAPS) The species richness of the IAPS was higher near the settlements than away from the settlements (Table 2a) and lower in the areas with fire marks than in the areas without fire marks (Table 2b). Similarly, the species richness was also significantly different $(\mathrm{p}<0.05)$ across the sampling sites, with the highest value at the Bhata Site.

\section{Impacts of IAPS on tree regeneration}

The sapling density of the tree species was calculated as a measure of tree regeneration in the study area. The sampling density declined significantly with the increasing cover of the IAPS suggesting that the IAPS had adverse effects on the regeneration of the tree species (Figure 5). 


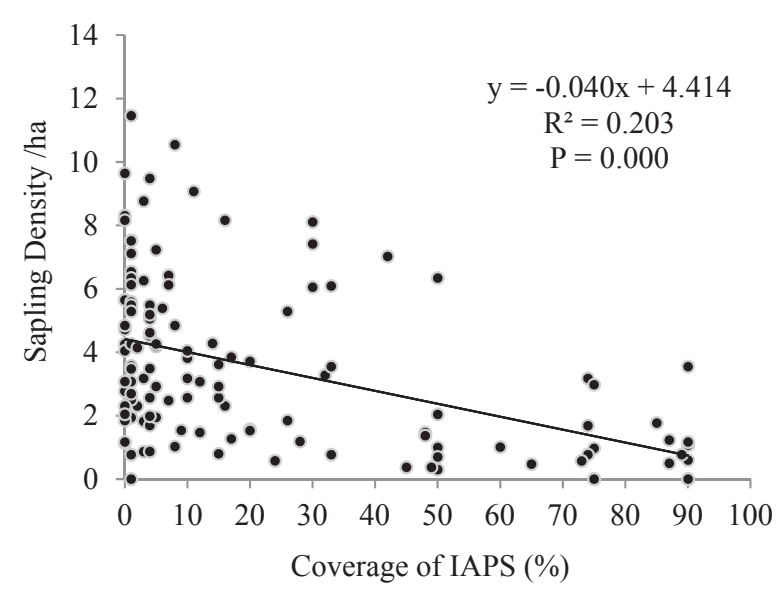

Figure 5: Variation of sapling density with coverage of IAPS. Each point in Figure represents a quadrat $(\mathrm{N}=130)$. The less number of points in the Figure is due to the overlapping of the data among the quadrats. The fitted line is based on the linear regression model.

\section{Discussion}

National parks are relatively less disturbed from the anthropogenic activities compared to the surrounding landscape. Therefore, the extent of plant invasions is expected to be low in the national parks. However, our data showed that more than half of the invasive alien plant species (IAPS) found in Nepal has already invaded the PNP. Three of the world's worst IAPS ( $C$. odorata, L. camara and $M$. micrantha) have invaded several localities inside the Park with potential negative impacts on the protected wildlife and native biodiversity. Due to the logistic and safety reasons, we could not cover the entire area of the Park for sampling the IAPS. There is possibility of finding the additional IAPS through more intensive sampling than the present one (study). However, the results of the present study revealed that the problem of plant invasions in the PNP is already alarming, requiring immediate management interventions.

There was spatial variation in the cover and richness of the IAPS. The higher cover and richness of the IAPS in the Bhata, Pratappur and Adhabhar Sites might be due to the effect of human activities. These three Sites were close to the settlements, and the local communities used the adjacent areas for grazing and collection of forest resources. Human movements and associated disturbances increase the propagule pressure of IAPS by dispersing seeds and other reproductive units, and provide opportunity for the establishment of the IAPS by reducing native vegetation cover (Hobbs and Huenneke, 1992). The frequency of the individual IAPS reported in this study is similar to the findings of Tiwari et al. (2005). For example, the most frequent species (C. odorata) in the PNP was also reported as the most frequent species in the forest of the Terai region (Tiwari et al. 2005). Among the 14 IAPS recorded in the PNP, 3 species (C. odaorata, $L$. camara and M. micrantha) are in the list of 100 of the world's invasive alien species (Lowe et al., 2004). Similarly, A. conyzoides, C. odorata, L. camara, M. micrantha and P. hysterophorus present in the PNP were also identified as the noxious invasive plants in the Asia Pacific region (Sankaran et al., 2005).

The high invasion of $C$. odorata in the PNP might be due to the prolific seed production capacity, availability of intermediate light intensity and high efficiency of competition for nutrition (Rejmanek and Richardson, 1996; Norbu, 2004). Sal forest of Terai region with relatively open canopy may provide suitable habitat for the proliferation of $\mathrm{C}$. odorata (Joshi, 2001). However at Bhata Site, $M$. micrantha was reported as the most problematic IAPS, and this could be due to the presence of wetlands associated with lakes (Lauki Daha and Devaki Daha) and streams (Bhata Khola and Jalvayu Khola). The moist land with open canopy is considered as the best habitat for the growth, reproduction and rapid colonization of M. micrantha (Siwakoti, 2007; Sapkota, 2012).

There was higher abundance of individual IAPS in the areas close to the settlements than in the areas away from the settlements within the PNP. Fugii et al. (2008) also reported high level of invasion of each IAPS near the settlements. Anthropogenic activities and animal movement near the settlements may help in arrival and distribution of IAPS propagules (Hobbs and Huenneke, 1992). The level of invasion was found to have declined with decreasing human activities in peri-urban areas (Karki, 2009).

Generally, mild forest fire provide suitable niche for the establishment of IAPS, and promotes their growth (de Rouw, 1991; Witkowski, 2000). However, impacts of fire may depend on intensity and frequency of fire. In the PNP, the cover and species richness of the IAPS was lower in the quadrats with fire marks than in the plots without such marks. Forest floor and grasslands 
are frequently burnt in the PNP to induce growth of forage species for wildlife. It was likely that severe fire might have eliminated propagules and seed bank of some IAPS.

In the PNP, the sapling density of the trees was found to have declined with the increase in the IAPS cover. High abundance of IAPS can modify the micro-habitat in such a way that it becomes hostile for seed germination and seedling growth of native species. IAPS release certain secondary metabolites i.e. allelochemicals that makes the chemical environment of soil unsuitable for germination of seeds of other species (Inderjit et al., 2008). IAPS are 'passengers' of deforestation and forest degradation at their early stage of colonization, which later change into 'drivers' by disrupting tree regeneration process (DalalClayton et al., 2014).

\section{Conclusion}

The presence of 14 IAPS (out of the 26 IAPS reported in Nepal) revealed that the PNP has already witnessed massive plant invasions. The widespread occurrence of three of the world's worst invasive species suggests that the Park Management has been ineffective in preventing introduction of the well-known invasive weed. In absence of specific management plan for the invasive species, it is highly likely that the extent of invasion of the previously established IAPS will increase, which may pose additional threats to the protected wildlife and native biodiversity. Furthermore, there is also a chance of introduction of new invasive species into the Park. Therefore, it is high time to integrate the management of the IAPS in the management plan of the Park. Additional research focusing on spatial distribution mapping of the invasive alien plant species and their impacts on native plant species and ecosystem are essential to better inform the Park management.

\section{Acknowledgements}

This work was supported by the University Grants Commission through its Faculty Research Grants Program. We are thankful to Dr. Lal Bahadur Thapa of the Central Department of Botany, Tribhuvan University and Mr. Nilambar Mishra, Chief Warden of the PNP for their support in the study. We are equally thankful to Mr. Yagya Raj Paneru for preparing the map of the study area.
We are grateful to the Department of National Park and Wildlife Conservation, and Parsa National Park for granting permission to work in PNP. Similarly, we are indebted to the National Herbarium and Plant Laboratories (KATH) and Tribhuvan University Central Herbarium (TUCH) for allowing us to check the herbarium specimens during plant identification.

\section{References}

Bhuju, U. R., Shakya, P. R. Basnet, T. B. and Shrestha, S. (2007). Nepal Biodiversity Resource Book. United Nations Environment Program (UNEP) and Ministry of Environment Science and Technology (MoEST), Government of Nepal, Kathmandu.

Bhuju, D. R., Shrestha, B. B. and Niraula, R. B. (2013). Study on Invasive Alien Species (IAS) as Drivers to Deforestation and Degradation of Forests in different physiographic regions of Nepal. A report submitted to REDD Cell, Ministry of Forests and Soil Conservation by BS JV_ API.

CBD (2002). Sixth Conference of the Parties, The Hague, Netherlands, 7-19 April 2002 : Decision Vi/23 : Alien species that threaten ecosystems, habitats or species to which is annexed guiding principles for the prevention, introduction and mitigation of impacts of alien species that threaten ecosystems, habitats or species. (http : // www. biodiv. org/; accessed on 14-Nov. 2014). Accessed on March 23, 2019.

Chettri, M. K. (1986). Effects of herbicides on Eupatorium adenophorum. [MSc Dissertation]. Central Department of Botany, Tribhuvan University, Kathmandu.

Dalal-Clayton, B. Bhadra, C., Chhetri, R. B., Nhantumbo, I., Milledge, S., Pradhan, K. M., Mathema, A. and Tilleard, S. (2014). Reducing Deforestation and Forest Degradation in Nepal : A Strategic Environmental and Social Assessment of Nepal's REDD+ Strategy. A Report prepared for the REDD Forestry and Climate Change Cell, Ministry of Forests and Soil Conservation, Nepal. 
Dangermond, E. M., Pardini, E. A. and Knight, T. M. (2010). Apparent competition with an invasive plant hastens the extinction of an endangered lupine. Ecology 91 (8) : 2261-2271.

de Rouw, A. 1991. The invasion of Chromolaena odorata (L. ) King \& Robinson (ex Eupatorium odoratum), and competition with the native flora, in a rain forest zone, south-west Cote d'Ivoire. Journal of Biogeography $18: 342-355$.

DNPWC (2003). Annual Report (2002/03). HMG/N Department of National Parks and Wildlife Conservation, Kathmandu.

DNPWC/PCP (2003). Resource Profile : Parsa Wildlife Reserve and Proposed Buffer Zone. Government of Nepal, Department of National Parks and Wildlife Conservation and Participatory Conservation Program (PCP), Kathmandu.

Donlan, C. J., Tershy, B. R., Campbell, K. and Cruz, F. (2003). Research for requiems : the need for more collaborative action in eradication of invasive species. Conservation Biology 17 (6) : 1850-1851.

Fugii, Y., Kurokawa, S. and Hiradate, S. (2008). Evolution of Invasive Alien Plants by modified FAO-WRA (2005) : Importance of Allelopathy in Weed Risk Assessment. [Abstract]. New York, USA : Fifth Congress on Allelopathy. Sarotoga Springs. pp. $73-74$.

Grierson, A. J. C. and Long, D. G. (1984). Flora of Bhutan, Vol. 1 (2). Edinburgh, UK : Royal Botanic Garden.

Grierson, A. J. C. and Long, D. G. (1987). Flora of Bhutan, Vol. 1 (3). Edinburgh, UK : Royal Botanic Garden.

Grierson, A. J. C. and Long, D. G. (1991). Flora of Bhutan, Vol. 2 (1). Edinburgh, UK : Royal Botanic Garden.

Grierson, A. J. C. and Long, D. G. (1999). Flora of Bhutan, Vol. 2 (2). Edinburgh, UK : Royal Botanic Garden.
Grierson, A. J. C. and Long, D. G. (2001). Flora of Bhutan, Vol. 2 (3). Edinburgh, UK : Royal Botanic Garden.

Hui, C., Richardson, D. M., Robertson, M. P., Wilson, J. R. U. and Yates, C. J. (2011). Macro-ecology meets invasion ecology : linking the native distributions of Australian acacias to invasiveness. Diversity and Distributions 17 : 872-883.

Hobbs, R. J. and Huenneke, L. F. (1992). Disturbance, diversity, and invasion : implications for conservation. Conservation Biology 6 (3) : 324-337.

Inderjit, Seastedt, T. R., Callaway, R. M. and Kaur, J. (2008). Allelopathy and plant invasions : traditional, co-generic, and bio-geographical approaches. Biological Invasions 10 (6) : 875-890.

Joshi, C. (2001). Invasive Banmara (Chromolaena odorata): Spatial Detection and Prediction. [M. Sc. Dissertation], International Institute for Geo-information Science and Earth Observation, Enschede, Netherland.

Karki, D. (2009). Ecological and Socio-Economic Impacts of Parthenium hysterophrus L. Invasion in Two Urban Areas in Nepal. [M. Sc. Dissertation], Central Department of Botany, Kathmandu, Nepal.

Kent, M. and Coker, P. (1994). Vegetation Description and Analysis : A Practical Approach. John Wiley \& Sons Ltd., Baffins Lane, Chichester, England.

Kohli, R. K., Jose, S., Singh, H. P. and Batish, D. R. (2009). Invasive Plants and Forest Ecosystems. New York, CRC Press, Taylor $\&$ Francis Group.

Kriticos, D. J., Sutherst, R. W., Brown, J. R., Adkins, S. W. and Maywald, G. F. (2003). Climate change and the potential distribution of an invasive alien plant : Acacia nilotica subspecies indica in Australia. Journal of Applied Ecology 40 : 111-124.

Lowe, S., Browne, M., Boudjelas, S. and de Poorter, M. (2004). 100 of the World's 
Worst Invasive Alien Species. A selection from the Global Invasive Species Database. The Invasive Species Specialist Group (ISSG), a specialist group of the Species Survival Commission (SSC) of the World Conservation Union (IUCN). 12pp. www. issg. org. Accessed on $7^{\text {th }}$ April, 2015.

Malla, S. B., Rajbhandari, S. B., Shrestha, T. B., Adhikari, P. M., Adhikari, S. R. and Shakya P. R. (1986). Flora of Kathmandu Valley. Bulletin of the Department of Medicinal Plants No. 11. Thapathali, Kathmandu, Nepal.

Miththapala, S. (2007). A strategy for addressing issues of aquatic invasive alien species in the Lower Mekong Basin. Colombo. IUCN : Mekong Wetland Biodiversity Program and Regional Species Conservation Program. The World Conservation Union (IUCN), Asia, Sri Lanka.

Murphy, S. T., Subedi, N., Jnawali, S. R., Lamichhane, B. R., Upadhyay, G. P., Kock, R. and Amin, R. (2013). Invasive Mikania in Chitwan National Park, Nepal : the threat to the greater one-horned rhinoceros Rhinoceros unicornis and factors driving the invasion. Oryx 47 (3) : 361-368.

Norbu, N. (2004). Invasion Success of Chromolaena odorata (L. ) King \& Robinson in the Terai of Nepal. [M. Sc. Dissertation], International Institute for Geo-information Science and Earth Observations, Enschede, Netherlands.

Polunin, O. and Stainton, A. (1984). Flowers of the Himalaya. Oxford University Press, New Delhi, India.

Press, J. R., Shrestha, K. K. and Sutton, D. A. (2000). Annotated Checklist of Flowering Plants of Nepal. The Natural History Museum, London.

Rai, R. K. and Scarborough, H. (2012). Valuing the Damage caused by Invasive Plant Species in a Low-income Community in Nepal. Working Paper, No. 74-12. South Asia Network for Development and Environmental Economics (SANDEE), Kathmandu, Nepal.
Rai, J. P. N. and Tripathi, R. S. (1982). Allelopathy as a factor contributing to dominance of Eupatorium. Indian Journal of Ecolog 9 : 14-20.

Rai, P. K. and Singh, J. S. 2020. Invasive alien plant species : Their impact on environment, ecosystem services and human health. Ecological Indicators, 111, 106020. DOI : 10. 1016/j. ecolind. 2019. 106020. Accessed on $15^{\text {th }}$ January, 2020.

Reaser, J. K., Meyerson, L. A., Cronk, Q., Poorter, M. D., Eldrege, L. G., Green, E., Kairo, M., Latasi, P., Mack, R. N., Mauremootoo, J., O'Dowd, D., Orapa, W., Sastroutomo, S., Saunders, A., Shine, C., Thrainsson, S. and Vaiutu, L. (2007). Ecological and socioeconomic impacts of invasive alien species in island ecosystems. Environmental Conservation 34 (2) : 98-111.

Rejmanek M. and Richardson D. M. (1996). What attributes make some plant species more invasive? Ecology 77 : 1655-1661.

Richburg, J. (2008). Invasive Plant Management : Guidelines for Managers. The Trustees of Reservations. http : //www. thetrustees. org/assets/documents/what-we-care-about/ Invasi ves-Plant-Guidelines-Final_Sep08. pdf. Accessed on $20^{\text {th }}$ November, 2014.

Sankaran, K. V., Murphy, S. T. and Sreenivasan, S. A. (2005). When good trees turn bad : the unintended spread of introduced plantation tree species in India. McKenzie, P., Brown, C., Jianghua, S. and Jian, W. (eds. ). Asia-Pacific Forestry Commission : The unwelcome guest. Proceedings of the Asia-Pacific Forest Invasion Species Conference. Kunming, Yunnan Province, China. pp. 39-47.

Sapkota, L. (2012). Ecology and management issues of Mikania micrantha in Chitwan National Park, Nepal. Banko Janakari 17 (2) : 27-39.

Shrestha, B. B. (2019). Management of invasive alien plants in Nepal : Current practices and future prospects. Garkoti, S. C., van Bloem, S. J., Fule, P. Z. and Semwal, R. 
L. (eds. ) Tropical Ecosystems : Structure, Functions and Challenges in the Face of Global Change. Springer, Singapore. pp, 45-68.

Shrestha, B. B., Shabbir, A. and Adkins, S. W. (2015). Parthenium hysterophorus in Nepal : a review of its weed status and possibilities for management. Weed Research 55 : 132-144.

Shrestha, B. B., Budha, P. B., Pagad, S. and Wong, L. J. (2017). Global Register of Introduced and Invasive Species - Nepal. Invasive Species Specialist Group ISSG. Checklist Dataset. https : //doi. org/10. 15468/4r0kkr accessed via GBIF. org. Accessed on November 2, 2017.

Shrestha, B. B., Pokhrel, K., Paudel, N., Poudel, S., Shabbir, A. and Adkins, S. W. (2019). Distribution of Parthenium hysterophorus and one of its biological control agents (Coleoptera : Zygogramma bicolorata) in Nepal. Weed Research 59 (6) : 467-478.

Siwakoti, M. (2007). Mikania weed : a challenge for conservationists. Our Nature 5 : 70-74.
Siwakoti, M. and Varma, S. K. (1999). Plant Diversity of Eastern Nepal : Flora of Plains of Eastern Nepal. Bishen Singh Mahendra Pal Singh, Dehradun, India.

Tiwari, S., Adhikari, B., Siwakoti, M. and Subedi, K. (2005). An Inventory and Assessment of Invasive Alien Plant Species of Nepal. IUCN, the World Conservation Union, Nepal.

Witkowski, E. T. F. (2000). Invasion intensity and regeneration potential of the non-native invasive plant Chromolaena odorata at St. Lucia, South Africa. Strathie, L. W. (ed. ). Fifth International Workshop on Biological control and Management of Chromolaena odorata. ARC-PPRI, Durban, South Africa. pp. 106-117.

Wu, Z. Y., Raven, P. H. and Hong, D. Y. (eds. ) (2011). Flora of China, Vol. 20-21 (Asteraceae). Science Press, Beijing and Missouri Botanical Garden Press, St. Louis. 